\title{
Compensatory Cellular Reactions to Nonsteroidal Anti-Inflammatory Drugs on Osteogenic Differentiation in Canine Bone Marrow-Derived Mesenchymal Stem Cells
}

\author{
Namgil $\mathrm{OH}^{1)}$, Sangho $\mathrm{KIM}^{1)}$, Kenji HOSOYA ${ }^{1)}$ and Masahiro OKUMURA ${ }^{1) *}$ \\ ${ }^{1)}$ Laboratory of Veterinary Surgery, Department of Veterinary Clinical Sciences, Graduate School of Veterinary Medicine, Hokkaido \\ University, Sapporo 060-0818, Japan
}

(Received 1 October 2013/Accepted 27 December 2013/Published online in J-STAGE 13 January 2014)

\begin{abstract}
The suppressive effects of nonsteroidal anti-inflammatory drugs (NSAIDs) on the bone healing process have remained controversial, since no clinical data have clearly shown the relationship between NSAIDs and bone healing. The aim of this study was to assess the compensatory response of canine bone marrow-derived mesenchymal stem cells (BMSCs) to several classes of NSAIDs, including carprofen, meloxicam, indomethacin and robenacoxib, on osteogenic differentiation. Each of the NSAIDs (10 $\mu \mathrm{M})$ was administered during 20 days of the osteogenic process with human recombinant IL-1 $\beta(1 \mathrm{ng} / \mathrm{m} l)$ as an inflammatory stimulator. Gene expression of osteoblast differentiation markers (alkaline phosphatase and osteocalcin), receptors of PGE $_{2}$ (EP2 and EP4) and enzymes for prostaglandin (PG) E2 synthesis (COX-1, COX-2, cPGES and mPGES-1) was measured by using quantitative reverse transcription-polymerase chain reaction. Protein production levels of alkaline phosphatase, osteocalcin and $\mathrm{PGE}_{2}$ were quantified using an alkaline phosphatase activity assay, osteocalcin immunoassay and $\mathrm{PGE}_{2}$ immunoassay, respectively. Histologic analysis was performed using alkaline phosphatase staining, von Kossa staining and alizarin red staining. Alkaline phosphatase and calcium deposition were suppressed by all NSAIDs. However, osteocalcin production showed no significant suppression by NSAIDs. Gene expression levels of $\mathrm{PGE}_{2}$-related receptors and enzymes were upregulated during continuous treatment with NSAIDs, while certain channels for $\mathrm{PGE}_{2}$ synthesis were utilized differently depending on

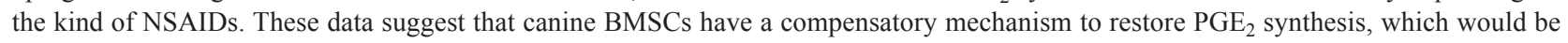
an intrinsic regulator to maintain differentiation of osteoblasts under NSAID treatment.

KEY WORDS: BMSCs, bone, canine, non-steroidal anti-inflammatory drug, osteoblast differentiation.
\end{abstract}

doi: 10.1292/jvms.13-0482; J. Vet. Med. Sci. 76(5): 629-636, 2014

Various kinds of nonsteroidal anti-inflammatory drugs (NSAIDs) have been used in animals and human beings as analgesic agents for pain management in the treatment of orthopedic diseases, including osteoarthritis and fracture. Therapeutic effects of NSAIDs can be evoked by inhibiting the enzyme activity of cyclooxygenase (COX), resulting in decreased synthesis of inducible prostaglandin (PG) $\mathrm{E}_{2}$, which is one of key mediators of inflammation and a stimulator of pain-sensitizing neurons [14, 28]. However, the effects of NSAIDs on the bone healing process have remained controversial $[2,5,6]$, because detrimental effects of NSAIDs on fracture healing are premised on the fact that one of the most consistent anabolic effect of $\mathrm{PGE}_{2}$ in osteogenesis is to promote differentiation of osteoblasts [7, 30].

Synthesis of $\mathrm{PGE}_{2}$ is a harmonized process of several enzymes, such as prostaglandin $\mathrm{H}_{2}$ synthases, including COX1 and $\mathrm{COX}-2$, and prostaglandin $\mathrm{E}$ synthases, consisting of cytosolic prostaglandin synthase (cPGES), microsomal prostaglandin synthase (mPGES)-1 and mPGES-2. In general, the constitutively expressing enzyme, COX-1 is ubiq-

\footnotetext{
*Correspondence to: Okumura, M., Laboratory of Veterinary Surgery, Department of Veterinary Clinical Sciences, Graduate School of Veterinary Medicine, Hokkaido University, Sapporo 060-0818, Japan. e-mail: okumuram@vetmed.hokudai.ac.jp (C)2014 The Japanese Society of Veterinary Science

This is an open-access article distributed under the terms of the Creative Commons Attribution Non-Commercial No Derivatives (by-nc-nd) License $<$ http://creativecommons.org/licenses/by-nc-nd/3.0/>.
}

uitous in most of cells for maintaining homeostasis, but COX-2 is an inducible enzyme that can be upregulated by various proinflammatory stimuli [35]. Downstream of COX enzymes, cPGES is also constitutively expressed and mainly coupled with the COX-1 enzyme [34]. In contrast, mPGES-1 is induced coordinately with the COX-2 enzyme, and it has a preference for COX-2 over COX-1 [21]. mPGES-2 can couple with either of the COX enzymes and is readily detected as COX-1 and cPGES, suggesting it is also a constitutive enzyme for maintenance of cell homeostasis [20].

Animal studies performed with COX-2 knockout mice revealed that the activity of the COX-2 enzyme has an important role in osteogenesis $[32,40]$. Fracture sites in wild-type animals showed delayed bone healing when they were treated with COX-2 inhibitors for a very long time with a high dose $[8,11,23,32,33]$. Although these data could explain that $\mathrm{PGE}_{2}$ is an essential molecule in fracture healing, the question still remains concerning why there is no clear evidence for delayed fracture healing as a result of COX-2 inhibitor treatment in clinical use. Furthermore, use of NSAIDs would be beneficial in some cases of bone healing, because biology of osteoblasts is likely to be negatively derived when $\mathrm{PGE}_{2}$ exceeds certain levels [26]; that is, overflow of $\mathrm{PGE}_{2}$ needs to be controlled in chronic inflammatory disease, such as rheumatoid arthritis [27].

An experimental study using fibroblasts from wild-type or COX knockout mice demonstrated overproduction of $\mathrm{PGE}_{2}$ by upregulated counterpart COX enzymes in COX-1- or COX-2-deficient cells when compared with intact cells [15]. 
Table 1. Sequences of primers used for real-time PCR

\begin{tabular}{|c|c|c|}
\hline Gene & Primer sequence ( $5^{\prime}$ to $\left.3^{\prime}\right)$ & Product size $(\mathrm{bp})$ \\
\hline$C O X-1$ & $\begin{array}{l}\text { (Forward) GGC AGT TCA GAA TGT TGT GC } \\
\text { (Reverse) GCA ATG CAC TCT GGT TAG GC }\end{array}$ & 162 \\
\hline$C O X-2$ & $\begin{array}{l}\text { (Forward) GCG AGG AAC CAA CAG CTT AC } \\
\text { (Reverse) TGA CAC GGG TTA CGT CAT GT }\end{array}$ & 171 \\
\hline cPGES & $\begin{array}{l}\text { (Forward) AAA AGG TGA ATC TGG CCA GTC ATG G } \\
\text { (Reverse) ATC CTC ATC ACC ACC CAT GTT GTT C }\end{array}$ & 172 \\
\hline$m P G E S-1$ & $\begin{array}{l}\text { (Forward) ACT GGC CAT GAG CCG CTG TG } \\
\text { (Reverse) TCC TGT GTT CAG CAC GCT GCC }\end{array}$ & 104 \\
\hline$E P 2$ & $\begin{array}{l}\text { (Forward) AAA TGG GAC CTC CAA GCT CT } \\
\text { (Reverse) ATG AAA CCC GAC AAC AGA GG }\end{array}$ & 124 \\
\hline EP4 & $\begin{array}{l}\text { (Forward) GTG TTT GGC TGT GCT CAG AA } \\
\text { (Reverse) CAT GGG TTC CCG TAT GAA TC }\end{array}$ & 110 \\
\hline$A L P$ & $\begin{array}{l}\text { (Forward) CCA AGC TCA ACA GAC CCT GA } \\
\text { (Reverse) GAG ACA CCC ATC CCA TCT CC }\end{array}$ & 102 \\
\hline Osteocalcin & $\begin{array}{l}\text { (Forward) AGG AAG CTT ACC AGC GCT TC } \\
\text { (Reverse) TGA CAA GGA CCC CAC ACT TG }\end{array}$ & 138 \\
\hline$G A P D H$ & $\begin{array}{l}\text { (Forward) CTG AAC GGG AAG CTC ACT GG } \\
\text { (Reverse) CGA TGC CTG CTT CAC TAC CT }\end{array}$ & 129 \\
\hline
\end{tabular}

Bone is one of the few organs that can be fully repaired under the best osteogenic milieu [31]. Based on these findings, it was hypothesized that differentiation of osteogenic cells can be maintained under NSAID treatment by utilizing other channels for $\mathrm{PGE}_{2}$ synthesis to restore the level of $\mathrm{PGE}_{2}$ during shortages caused by the differences in selectivity of COX-1/COX-2 in each type of NSAID. The purpose of this study was to confirm the cellular responses to NSAIDs, such as carprofen, meloxicam, indomethacin and robenacoxib, during differentiation into osteoblasts from canine bone marrow-derived mesenchymal stem cells (BMSCs).

\section{MATERIALS AND METHODS}

Collection and culture of canine BMSCs: All experimental protocols were reviewed and approved by the Animal Care and Use Committee of Hokkaido University. Canine bone marrow cells were harvested from the proximal humeri of three 1-year-old female beagle dogs. Approximately $2 \mathrm{ml}$ of bone marrow was aspirated into a heparinized syringe and was immediately suspended in Dulbecco's Modified Eagle Medium (DMEM; GIBCO, Grand Island, NY, U.S.A.). The cells in the medium were promptly centrifuged at $800 \times g$ for $20 \mathrm{~min}$. Mononuclear cell layers were transferred into a

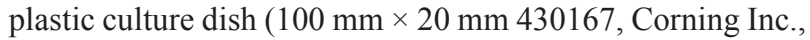
Corning, NY, U.S.A.) containing DMEM (GIBCO) with $10 \%$ heat-inactivated fetal bovine serum (FBS) and maintained in an incubator at $37^{\circ} \mathrm{C}$ with a humidified $5 \% \mathrm{CO}_{2}$ atmosphere. From the day when outgrowing cell colonies were observed, the medium was replaced every 3 days with elimination of the non-adherent cell fraction until adherent cells proliferate and became sub-confluent, which usually took about 10 days. Cells from the second passage were used in this experiment.

Cell viability assay: Carprofen (LKT Laboratories, Inc., St. Paul, MN, U.S.A.), meloxicam (Wako, Pure Chemical
Industries, Osaka, Japan), indomethacin (Wako) and robenacoxib (Novartis Animal Health US, Inc., Greensboro, $\mathrm{NC}$, U.S.A.) were prepared with different concentrations to achieve final concentrations of $0.01,0.1,1,10$ and $100 \mu \mathrm{M}$ in culture medium. Canine BMSCs were placed at a density of $5 \times 10^{3}$ cells in each well of a 96-well plate (Costar 3595, Corning Inc.) with $100 \mu \mathrm{l}$ culture medium. After $24 \mathrm{hr}$ of incubation for cell adaptation to the culture conditions, each concentration of drugs was treated for $48 \mathrm{hr}$ of the exponential growth phase. Cell viability was determined by a colorimetric assay based on the conversion of 3-(4,5-dimethyl2-thiazol) 2,5-diphenyl-2H-tetrazolium bromide (MTT; Wako) to a formazan pigment by mitochondrial enzymes in surviving cells during a 4-hr of incubation period [19]. Colorimetric measurement was performed using a microplate photometer (Multiskan FC, Thermo Fisher Scientific Inc., Waltham, MA, U.S.A.) at $570 \mathrm{~nm}$. All samples were evaluated in triplicate.

Establishment of inflammatory condition: The optimal concentration of recombinant human interleukin-1 $\beta$ (rhIL$1 \beta$, Wako) to trigger mRNA expression of inflammatory enzymes for $\mathrm{PGE}_{2}$ synthesis, such as COX-2 and mPGES-1, was confirmed. Briefly, after canine BMSCs were cultured under serum-free conditions for $24 \mathrm{hr}, 0.1,1$ and $10 \mu \mathrm{M}$ of rhIL-1 $\beta$ were supplemented into the medium. Gene expressions were analyzed at $2 \mathrm{hr}$ after each rhIL- $1 \beta$ stimulus using quantitative real-time polymerase chain reaction (qRT-PCR) as described in the section concerning analysis of gene expression.

Induction of osteogenic differentiation: Osteogenic differentiation was performed using canine BMSCs at the second passage. As a negative control, canine BMSCs were cultured in basal medium, DMEM, and as a positive control, osteogenic differentiation of the cells was induced by using conventional osteogenic medium, DMEM containing $0.1 \mu \mathrm{M}$ dexamethasone (Sigma, St. Louis, MO, U.S.A.), $10 \mathrm{mM}$ 
A

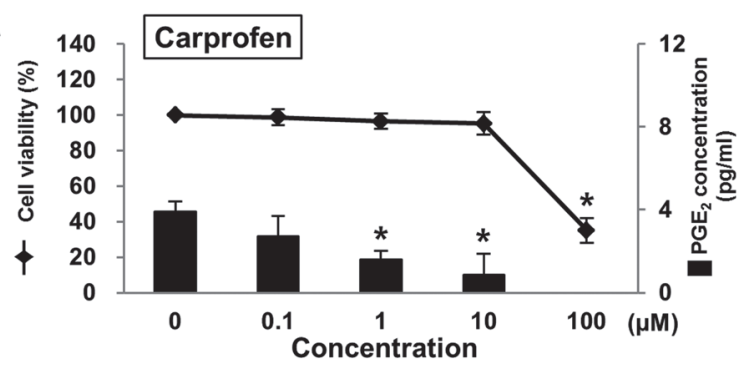

B

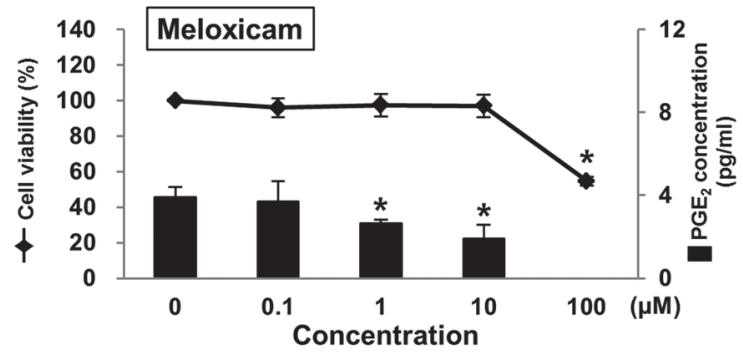

C

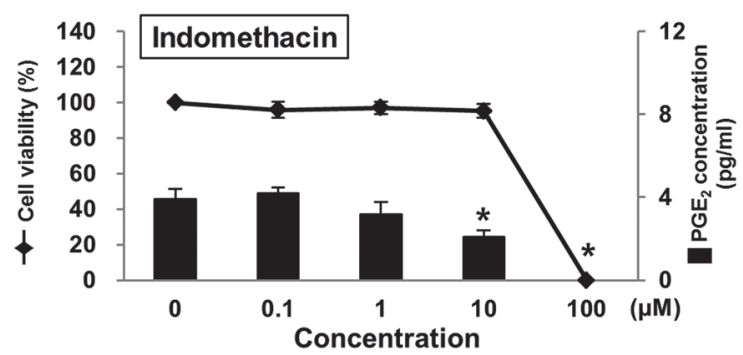

D

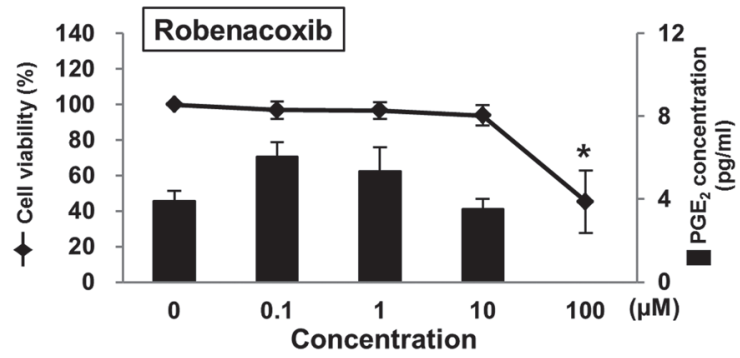

Fig. 1. Effects of carprofen (A), meloxicam (B), indomethacin (C) and robenacoxib (D) on viability and $\mathrm{PGE}_{2}$ synthesis in canine bone marrow-derived mesenchymal stem cells. Cell viability was determined using MTT assay after drug treatment for $48 \mathrm{hr}$. Production of $\mathrm{PGE}_{2}$ (C) was quantified by ELISA after $24 \mathrm{hr}$ of cell culture with $0.1,1$ and $10 \mu \mathrm{M}$ of NSAIDs. Data are means \pm SD from three independent experiments that were performed in triplicate. ${ }^{*} p<0.05$.

$\beta$-glycerophosphate (Sigma) and $50 \mathrm{mg} / \mathrm{ml}$ L-ascorbic acid (Wako). To observe effects of NSAIDs on the colony formation of alkaline phosphatase (ALP) positive cells, canine BMSCs were seeded in a multiple micro-mass manner at a density of $2 \times 10^{4}$ cells per a drop of $5 \mu l$ basal medium in 12-well, flat-bottomed culture plates (Costar 3513, Corning Inc.). After the cells adhered to the plate, the media were

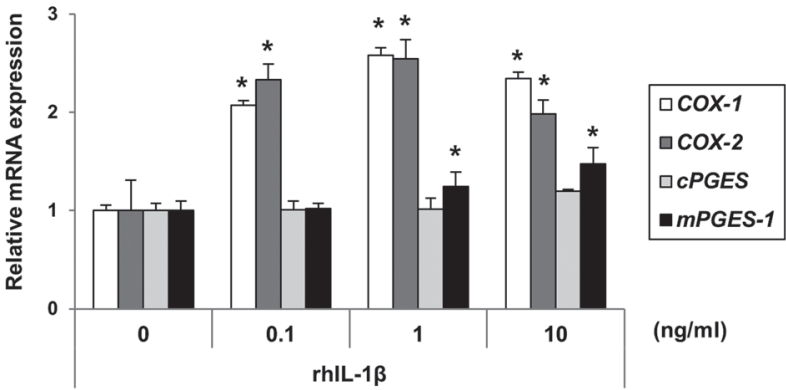

Fig. 2. Effects of recombinant human interleukin-1 $\beta$ (rhIL-1 $\beta$ ) on mRNA expression of enzymes for $\mathrm{PGE}_{2}$ synthesis. Canine bone marrow-derived mesenchymal stem cells were stimulated with each concentration of rhIL-1 $\beta(0.1,1$ and $10 n \mathrm{~g} / \mathrm{m} l)$ after $24 \mathrm{hr}$ of incubation in serum-free medium. Gene expression at $2 \mathrm{hr}$ was analyzed using quantitative real-time polymerase chain reaction. Data are means $\pm \operatorname{SD}(\mathrm{n}=3)$. * $p<0.05$.

changed every other day with or without NSAIDs for 20 days.

Quantification of $P G E_{2}$ synthesis: The level of endogenous $\mathrm{PGE}_{2}$ in culture supernatant was measured using a Prostaglandin E2 Parameter Assay Kit (R\&D Systems, Minneapolis, MN, U.S.A.) according to the instructions of manufacturer. Briefly, after the cells were cultured in serumfree medium for $24 \mathrm{hr}, \mathrm{PGE}_{2}$ production was measured at 0 , 24 and $48 \mathrm{hr}$ under inflammatory conditions with $1 \mathrm{ng} / \mathrm{ml}$ of rhIL-1 $\beta$. Effects of NSAIDs on $\mathrm{PGE}_{2}$ synthesis were evaluated by supplementation with $10 \mu \mathrm{M}$ of carprofen, meloxicam, indomethacin or robenacoxib.

Analysis of gene expression: Extraction of total cellular RNA was performed by disruption of cultured BMSCs with TRIzol reagent (Invitrogen, Life Technologies, Carlsbad, CA, U.S.A.). Total RNA was precipitated by centrifugation $\left(15,000 \mathrm{~g}, 20 \mathrm{~min}, 4^{\circ} \mathrm{C}\right)$ of aqueous phase with isopropanol. Pellets were washed with $70 \%$ ethanol and dissolved in $0.1 \%$ $\mathrm{v} / \mathrm{v}$ diethyl pyrocarbonate (DEPC)-treated water after drying in room air. The revers-transcription reaction performed using Moloney Murine Leukemia Virus Teverse Transcriptase (M-MLV RT; Invitrogen). The levels of gene expression were detected by using qRT-PCR in Rotor-Gene Q thermal cycler, (Qiagen, Hilden, Germany) with KAPA SYBR FAST qPCR Master Mix (KAPA Biosystems, Boston, MA, U.S.A.). The acquired data were analyzed by normalization to GAPDH as an internal control. All sequences of primers used in this experiment are listed in Table 1.

Intracellular ALP activity: Cell layers were washed twice with ice-cold phosphate-buffered saline (PBS) and lysed in $10 \mathrm{mM}$ Tris- $\mathrm{HCl}$ solution ( $\mathrm{pH} 7.4$ ) containing $0.05 \%(\mathrm{v} / \mathrm{v})$ Triton X-100 (ICN Biomedicals Inc., Aurora, OH, U.S.A.). After vigorous shaking and $30 \mathrm{~min}$ of sonication, supernatants of the cell lysates were separated by centrifugation at $20,000 \times g$ for $30 \mathrm{~min}$ and were stored at $-80^{\circ} \mathrm{C}$ until analysis. To access ALP activity of the cells, samples were thawed and reacted with $P$-nitrophenyl phosphate (Sigma) for 10 $\min$ at $37^{\circ} \mathrm{C}$ in substrate solution ( $\left.\mathrm{pH} 10.5\right)$, which contained $1 \mathrm{mg} / \mathrm{ml} P$-nitrophenyl phosphate, $100 \mathrm{mM}$ glycine, $1 \mathrm{mM}$ 


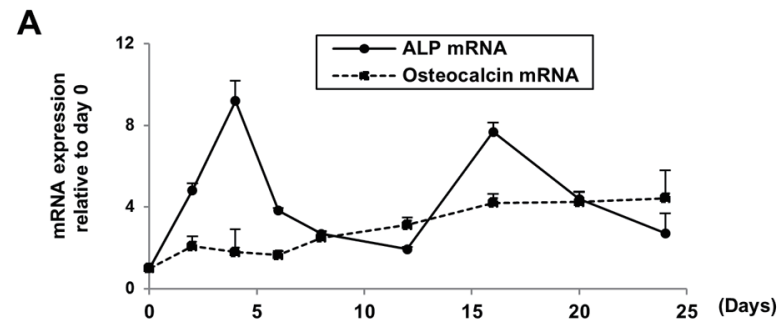

B

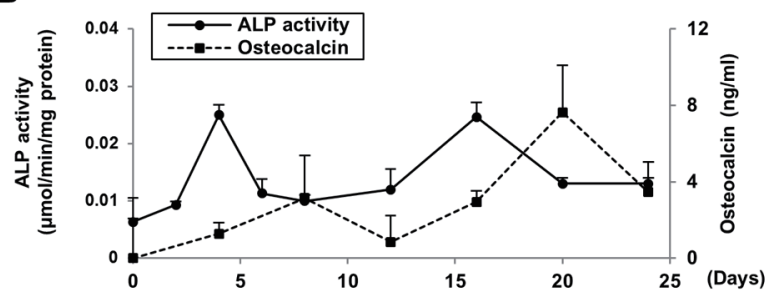

C
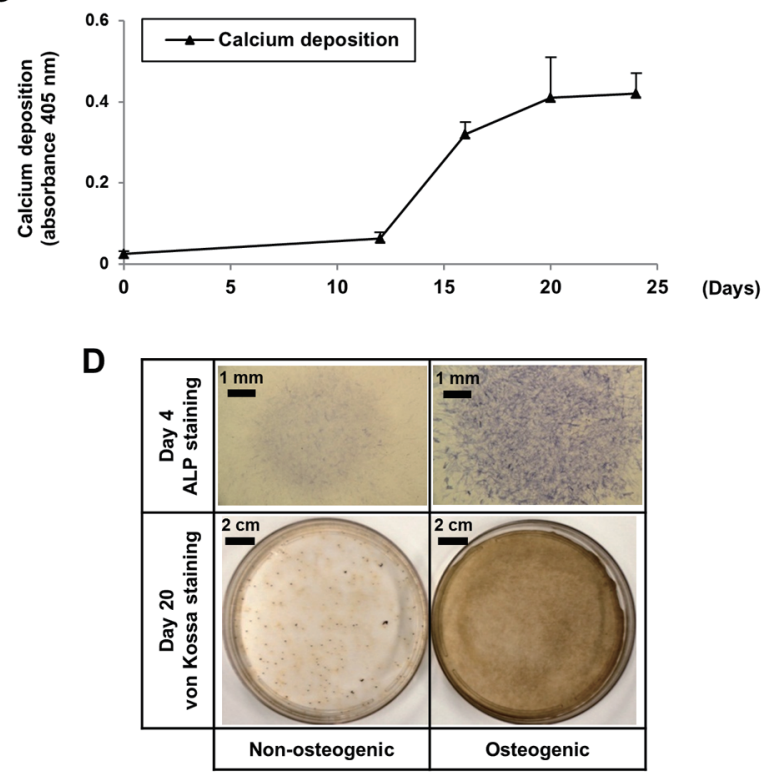

Fig. 3. Differentiation of osteoblasts in canine bone marrow-derived mesenchymal stem cells. Gene expression (A) was analyzed using quantitative real-time polymerase chain reaction. Enzyme activity of ALP (B) was measured by colorimetric assay using $p$ nitrophenylphosphate. Osteocalcin (B) was quantified by ELISA. Level of calcification (C) was quantified by Alizarin red S assay. Morphological analysis (D) was performed using ALP staining and von Kossa staining. Data are means $\pm \mathrm{SD}(\mathrm{n}=3)$.

$\mathrm{MgCl}_{2}$ and $1 \mathrm{mM} \mathrm{ZnCl}$. The released $P$-nitrophenol was measured by using a microplate photometer (Multiskan FC, Thermo Fisher Scientific Inc.) at $405 \mathrm{~nm}$ and normalized using the total protein concentration measured by the modified Bradford method (Bio-Rad Laboratories, Inc., Hercules, CA, U.S.A.) [3]. The ALP activity was expressed as $\mu \mathrm{mol} / \mathrm{min} /$ $\mathrm{mg}$ protein.

Quantification of osteocalcin production: Osteocalcin secreted by mature osteoblasts was evaluated using an Intact Human Osteocalcin EIA Kit (Biomedical Technologies Inc.,
Stoughton, MA, U.S.A.) according to the manufacturer's instructions. Culture supernatants were collected during medium change and were stored at $-80^{\circ} \mathrm{C}$ until the day they were quantified.

Quantification of extracellular calcium deposition: The amounts of extracellular matrix mineralized during osteoblast differentiation were compared by a colorimetric quantification method using an Alizarin red S (ARS, Sigma)-based assay [10]. Briefly, the cell layer in the well was washed with PBS and fixed in $10 \%(\mathrm{v} / \mathrm{v})$ formaldehyde at room temperature for $15 \mathrm{~min}$. After washing twice with distilled water, the plate was incubated with $40 n \mathrm{M}$ ARS ( $\mathrm{pH}$ 4.1) per well for $20 \mathrm{~min}$. Unincorporated dye was washed away with distilled water and aspirated. The dye was extracted by detachment of cell layers with $10 \%(\mathrm{v} / \mathrm{v})$ acetic acid and transferred to a microcentrifuge tube. The slurry was centrifuged at 20,000 $\times$ $g$ for $15 \mathrm{~min}$ after dissolution by heating at $85^{\circ} \mathrm{C}$ for $10 \mathrm{~min}$. The optical density of the supernatant was read by a microplate photometer (Multiskan FC, Thermo Fisher Scientific Inc.) at a wavelength of $405 \mathrm{~nm}$.

Morphological evaluation: The early period of differentiation of osteoblasts from canine BMSCs was observed using ALP staining. Briefly, the cells were washed with PBS and fixed with $4 \%$ paraformaldehyde for $2 \mathrm{~min}$. After rinsing, the cells were incubated in $0.1 \mathrm{M}$ Tris- $\mathrm{HCl}$ buffer $(\mathrm{pH}$ 9.3) containing $0.25 \%(\mathrm{w} / \mathrm{v})$ naphthol-AS-BI-phosphoric acid sodium salt (Sigma) and $0.75 \%(w / v)$ fast blue RR salt (Sigma) at $37^{\circ} \mathrm{C}$ for $30 \mathrm{~min}$.

Calcium deposition in the matrix of differentiated osteoblasts was confirmed using von Kossa staining. Briefly, the cells fixed with $4 \%$ paraformaldehyde for $2 \mathrm{~min}$ were treated with $2 \%$ silver nitrate (Wako) solution and placed under ultraviolet light at room temperature for $1 \mathrm{hr}$. After rinsing, the cells were bleached in 5\% sodium thiosulfate (Wako) for 2 min.

Statistics: Data were statistically analyzed by performing the nonparametric Mann-Whitney U test using commercial software (SPSS, version 12.0.1, SPSS Inc., Chicago, IL, U.S.A.). All data were expressed as means \pm standard deviations (SDs). Values of $p<0.05$ were considered to be statistically significant.

\section{RESULTS}

Doses of NSAIDs inhibiting PGE $E_{2}$ synthesis under inflammatory conditions without effects on cell viability: Effects of NSAIDs on viability of canine BMSCs were assessed quantitatively by MTT assay. Cell culture for $48 \mathrm{hr}$ resulted in no significant effects on cell viability for all NSAIDs at concentrations up to $10 \mu \mathrm{M}$ (Fig. 1A-1D). The optimal concentrations of rhIL-1 $\beta$ to induce enzymes responsible for inflammatory $\mathrm{PGE}_{2}$ synthesis were assessed by confirmation of the expression of genes, such as COX-2 and mPGES-1. At $2 \mathrm{hr}$ after stimulation with $0.1,1$ and $10 \mathrm{ng} / \mathrm{ml}$ of rhIL$1 \beta$, the expression levels of COX-1 and COX-2 mRNA were increased (Fig. 2). The gene expression of mPGES-1 was increased by 1 and $10 \mathrm{ng} / \mathrm{ml}$ of rhIL-1 $\beta$, indicating that inflammatory conditions could be triggered by rhIL-1 $\beta$ at con- 
A

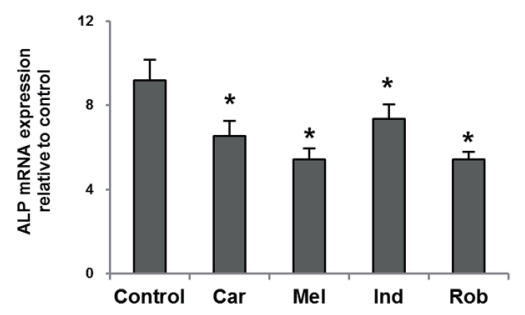

B

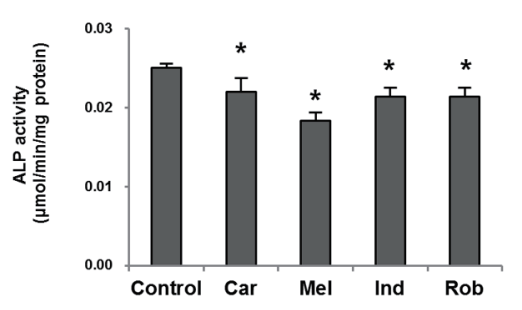

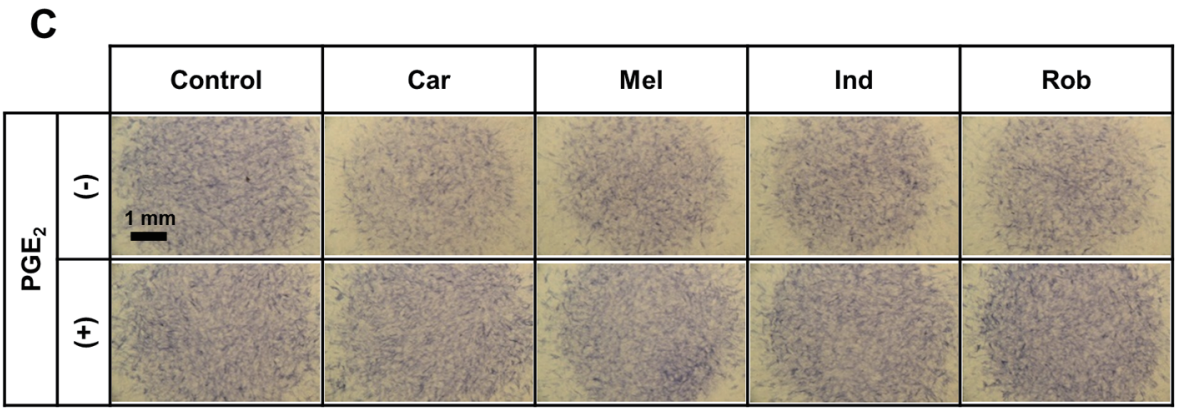

D

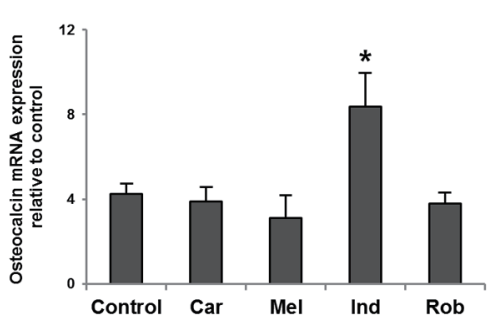

$\mathbf{E}$

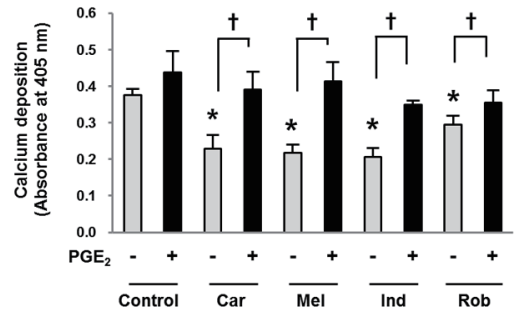

Fig. 4. Effects of NSAIDs on differentiation of osteoblasts in canine bone marrow-derived mesenchymal stem cells. Gene expression (A, D) was analyzed using quantitative real-time polymerase chain reaction. Enzyme activity of ALP (B) was measured by colorimetric assay using $p$-nitrophenylphosphate. Morphological analysis (C) was performed using ALP staining. Level of calcification (E) was quantified by Alizarin red S assay on day 20. Expression levels of ALP (A, B and C) were analyzed on day 4. In groups for recovery, $10 \mathrm{nM}$ of $\mathrm{PGE}_{2}$ was added (C and $\left.\mathrm{E}\right)$. Car, carprofen $(10 \mu \mathrm{M})$; $\mathrm{Mel}$ : meloxicam $(10 \mu \mathrm{M})$; Ind, indomethacin $(10 \mu \mathrm{M})$; Rob, robenacoxib $(10 \mu \mathrm{M})$. Data are means $\pm \mathrm{SD}$ $(\mathrm{n}=3) .{ }^{*} p<0.05 ; \uparrow p<0.05$ between 2 columns.

centration $\geq 1 n \mathrm{~g} / \mathrm{ml}$. In the present study, $1 n \mathrm{~g} / \mathrm{m} l$ of $\mathrm{rhIL}-1 \beta$ was supplemented into osteogenic medium to induce the expression of COX-2 and mPGES-1. At $24 \mathrm{hr}$ during cell culture under inflammatory conditions, $\mathrm{PGE}_{2}$ synthesis was dose-dependently suppressed by NSAIDs, except for robenacoxib, at concentrations $\leq 10 \mu \mathrm{M}$, which were shown to not interfere with cell viability (Fig. 1A-1D). The dose for each NSAID in this experiment was $10 \mu \mathrm{M}$ and was selected to inhibit COX activity.

Differentiation of osteoblasts from canine BMSCs: The time-course expression levels of markers for osteoblasts were changed during osteogenic differentiation. The levels of ALP expression fluctuated after the highest expression was observed on day 4. Osteocalcin expression gradually increased after the peak of ALP expression, which was followed by an increase in calcium deposition. Calcification in the cellular matrix reached the maximum level on day 20 (Fig. 3C), at which point osteocalcin secretion was detected at its highest level. Differentiation of osteoblasts in canine BMSCs was also supported by morphologic analysis (Fig. 3D), including colony formation of ALP-positive cells on day 4 and calcified matrix formation on day 20 .

Expression of osteoblastic markers during NSAID treatment: Effects of NSAIDs on differentiation of osteoblasts were evaluated based on the expression levels of ALP, osteocalcin and calcification on the day when each osteoblastic marker was expressed at the highest level. On day 4, the expression level of ALP mRNA (Fig. 4A), ALP activity (Fig. 4B) and colony formation of ALP-positive cells (Fig. 4C) were decreased by all the NSAIDs. Suppressed differentiation of ALP-positive cells by NSAIDs was restored by supplementation of $\mathrm{PGE}_{2}$ (Fig. 4C). The expression level 
A

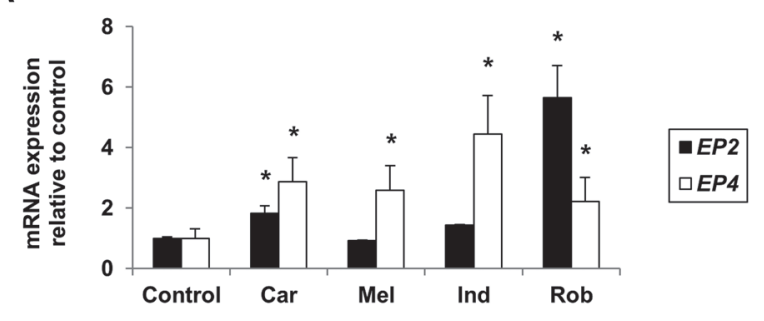

B

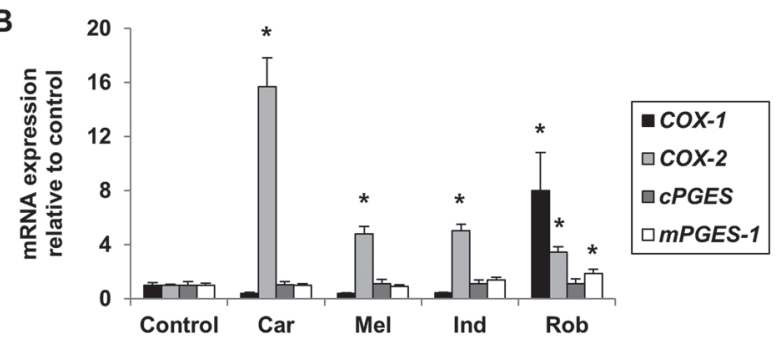

C

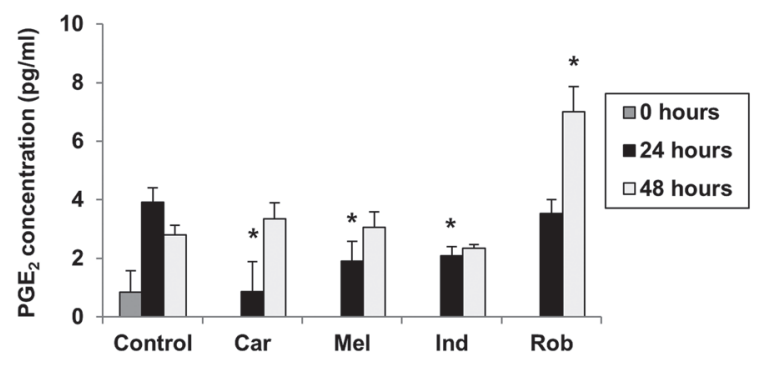

Fig. 5. Compensatory response under NSAID treatment during osteoblast differentiation in canine bone marrow-derived mesenchymal stem cells. Gene expression was analyzed on day 4 using quantitative real-time polymerase chain reaction (A and B). Production of $\mathrm{PGE}_{2}(\mathrm{C})$ was quantified by ELISA. Car, carprofen (10 $\mu \mathrm{M})$; Mel, meloxicam (10 $\mu \mathrm{M})$; Ind, indomethacin (10 $\mu \mathrm{M})$; Rob, robenacoxib $(10 \mu \mathrm{M})$. Data are means $\pm \mathrm{SD}(\mathrm{n}=3) .{ }^{*} p<0.05$.

of osteocalcin mRNA showed no decrease due to treatment with NSAIDs on day 20 (Fig. 4D). Synthesis of protein of osteocalcin also showed no significant difference between the control and groups receiving NSAID treatment (data not shown). The level of calcification was decreased by NSAIDs on day 20 , which was restored by continuous supplementation with $\mathrm{PGE}_{2}$ (Fig. 4E).

Expressions of $P G E_{2}$-related genes and synthesis of $P G E_{2}$ under NSAIDs treatment: Continuous treatment with NSAIDs induced upregulation of genes for $\mathrm{PGE}_{2}$-related receptors (Fig. 5A) and enzymes (Fig. 5B). Gene expression levels of $\mathrm{PGE}_{2}$ receptors, such as EP2 and EP4, were upregulated on day 4 by NSAIDs, except in the case of meloxicam and indomethacin for EP2 mRNA expression. Expression of COX-2 mRNA was also upregulated by NSAIDs on day 4 and was more increased by carprofen, about 4-fold, than by the other NSAIDs. The rates of $\mathrm{PGE}_{2}$ synthesis were suppressed for $24 \mathrm{hr}$ by NSAIDs (Fig. 5C) and were negatively correlated with the upregulated expression patterns of COX-2 mRNA.
Suppressed $\mathrm{PGE}_{2}$ synthesis was restored in each group at 48 $\mathrm{hr}$, at which time the amount of $\mathrm{PGE}_{2}$ synthesized was about 2 -fold higher in robenacoxib group than in other groups.

\section{DISCUSSION}

In the present study, canine BMSCs differentiated into osteoblasts under inflammatory conditions of COX-2-induced $\mathrm{PGE}_{2}$ synthesis. Serial changes in the expressions of osteoblastic markers during the differentiation were confirmed by upregulation of ALP activity in pre-osteoblasts, followed by an increase of osteocalcin synthesis in mature osteoblasts and by calcification of matrix, which was previously shown to be correlated with osteoblastic differentiation of mesenchymal stem cells in humans [16] and rats [22]. After the peak of ALP expression, the cells accumulated to form nodules, which were the core for starting of calcified matrix formation. Then, in the vacant space around the nodules, the cells continuously proliferated and formed new nodules after the second peak of ALP expression. This is why two peaks of ALP and osteocalcin expression can be observed with the same patterns in Fig. 3A.

Continuous treatment of NSAIDs partially suppressed the osteogenic process in canine BMSCs, such as ALP expression and calcification. While expression of ALP was decreased by NSAIDs at its peak, the level of expression was still close to that of the control on day 4 (Fig. 4A and 4B) and could have gradually increased with differentiation into mature osteoblasts, resulting in unsuppressed expression of osteoclacin on day 20. Expression of osteocalcin mRNA decreased by NSAIDs during differentiation of osteoblasts in human BMSCs on day 4 [38]. However, we detected uninhibited expression of mRNA and protein production of osteocalcin when its expression was maximal, suggesting that NSAIDs would only temporarily suppress expression of osteocalcin. The level of calcification on day 20 was somewhat suppressed, which would be related to delayed ALP expression due to insufficiency of $\mathrm{PGE}_{2}$ synthesis. It is important to note that the deficiency in $\mathrm{PGE}_{2}$ in the osteogenic milieu under treatment with NSAIDs could be reversed by the osteogenic cells, leading to prevention of markedly derailed osteoblast differentiation.

Inhibitory effects of NSAIDs on $\mathrm{PGE}_{2}$ synthesis in canine BMSCs are caused by partial blockage of the COX-1 or COX-2 pathway, depending on the selectivity of the drugs for COXs. Expressions of genes for inflammatory $\mathrm{PGE}_{2}$ synthesis, such as COX-2 and mPGES-1 mRNA, were induced by $1 \mathrm{ng} / \mathrm{m} l$ of rhIL-1 $\beta$, which was also shown to be the concentration that stimulates synthesis of protein of COX-2 in human BMSCs [38]. Under this condition, carprofen, meloxicam and indomethacin showed significant suppression of $\mathrm{PGE}_{2}$ synthesis at $24 \mathrm{hr}$, supporting the expected pharmacological inhibitory effects on inflammatory $\mathrm{PGE}_{2}$ synthesis. However, restoration of the level of $\mathrm{PGE}_{2}$ during shortage was observed in every NSAID group at $48 \mathrm{hr}$, indicating that there would be some intrinsic mechanisms to correct shortages of $\mathrm{PGE}_{2}$ in canine BMSCs.

Upregulated expressions of receptors for $\mathrm{PGE}_{2}$, such as 
EP2 and EP4, could be an effective way to increase sensitivity to $\mathrm{PGE}_{2}$. It has been demonstrated that endogenous $\mathrm{PGE}_{2}$ could induce COX-2 expression via a PG-mediated auto-amplification loop by stimulating EP2 and EP4 in osteoblasts $[24,29]$. These results imply that increased expression of EP2 or EP4 acts not only as a part of the corrective mechanism for $\mathrm{PGE}_{2}$ shortage but also as an enhancer for osteogenic differentiation. Furthermore, EP2 and EP4 have been implicated in the bone anabolic effect of $\mathrm{PGE}_{2}[1,18,25]$. A study performed with selective agonists for $\mathrm{PGE}_{2}$ receptors and cells cultured from COX-2 knockout mice demonstrated that signaling via EP4 was more likely to play an important role in fracture repair than that via EP2 [37]. It is probable that increased expression of EP4 contributes to the upregulated expression of osteocalcin mRNA during indomethacin treatment (Fig. 4D).

Significantly increased expression of COX-2 mRNA was also detected and was negatively correlated with suppression of $\mathrm{PGE}_{2}$ synthesis. Furthermore, expression of COX-1 mRNA was upregulated by robenacoxib, while it is generally known to express continuously. The rapid rate of restoration via the upregulated COX-1 channel would be the reason why synthesis of $\mathrm{PGE}_{2}$ was not suppressed at $24 \mathrm{hr}$ of treatment with robenacoxib. Robenacoxib may have a relatively wider safety margin due to fast recovery of $\mathrm{PGE}_{2}$ after treatment, while it has been reported as a COX-2 selective inhibitor [13]. These results indicate that both COX-1 and COX-2 could be induced by $\mathrm{PGE}_{2}$ shortage to play physiological roles in compensation of $\mathrm{PGE}_{2}$ in canine BMSCs. Therefore, differentiation of osteoblasts would be partially affected by NSAIDs, depending on the net level of $\mathrm{PGE}_{2}$ that would be maintained by compensatory upregulation of COX-1/COX2 with or without EP2/EP4, while the efficiency of synthesis of $\mathrm{PGE}_{2}$ is further affected by COX-2 than by COX-1 [15].

Suppressive effects of NSAIDs on osteogenesis would be minimal in clinical short-term use for analgesic purposes. The maximum plasma concentrations of carprofen [17], meloxicam [39], indomethacin [12] and robenacoxib [13] in dogs have been determined in kinetic studies: $76.29 \mu \mathrm{M}$ (20.60 $\mu \mathrm{g} / \mathrm{m} l$ at $4.00 \mathrm{mg} / \mathrm{kg} /$ dose s.c.), $2.09 \mu \mathrm{M}(0.78 \mu \mathrm{g} / \mathrm{m} l$ at $0.20 \mathrm{mg} / \mathrm{kg} / \mathrm{dose}$ s.c. $), 58.38 \mu \mathrm{M}(20.9 \pm 4.5 \mu \mathrm{g} / \mathrm{ml}$ at $10.00 \mathrm{mg} / \mathrm{kg} /$ dose p.o. $)$ and $2.01 \mu \mathrm{M}(0.66 \mu \mathrm{g} / \mathrm{m} l$ at $1.00 \mathrm{mg} /$ $\mathrm{kg} /$ dose s.c.), respectively. These studies indicate that the doses of meloxicam and robenacoxib used in this experiment were over their maximum plasma concentrations, but that of carprofen was not. Because analgesic effects of NSAIDs are attained not only by peripheral inhibition of synthesis of $\mathrm{PGE}_{2}$ but also by an increase in the threshold in nociceptive neurons at the central site [4] and the concentration of NSAIDs in peripheral tissue is lower than in plasma concentration [9], analgesic doses of NSAIDs would hardly affect osteogenic differentiation at the site of fracture. However, fracture patients who need analgesic treatment with NSAIDs for a longer-term are recommended to be prescribed with NSAIDs that offer a more secure compensatory response to shortage of $\mathrm{PGE}_{2}$ in osteogenic cells, since long-term treatment with some NSAIDs has been shown to have effects that minimize heterotopic bone formation after arthroplasty [36].
In conclusion, canine BMSCs have a compensatory mechanism for NSAIDs, which appears to be a reversible switch that regulates the level of $\mathrm{PGE}_{2}$ for maintenance of osteogenesis. These data could be used to explain the discrepancy between the suppressive effect of NSAIDs on osteogenesis in vitro and the rarely reported deterioration of bone healing during clinical use of NSAIDs as pain-killers.

\section{REFERENCES}

1. Alander, C. B. and Raisz, L. G. 2006. Effects of selective prostaglandins E2 receptor agonists on cultured calvarial murine osteoblastic cells. Prostaglandins Other Lipid Mediat. 81: 178-183. [Medline] [CrossRef]

2. Barry, S. 2010. Non-steroidal anti-inflammatory drugs inhibit bone healing: a review. Vet. Comp. Orthop. Traumatol. 23: 385392. [Medline] [CrossRef]

3. Bradford, M. M. 1976. A rapid and sensitive method for the quantitation of microgram quantities of protein utilizing the principle of protein-dye binding. Anal. Biochem. 72: 248-254. [Medline] [CrossRef]

4. Cashman, J. N. 1996. The mechanisms of action of NSAIDs in analgesia. Drugs 52 (Suppl. 5): 13-23. [Medline] [CrossRef]

5. Cottrell, J. and O'Connor, J. P. 2010. Effect of non-steroidal anti-inflammatory drugs on bone healing. Pharmaceuticals (Ott.) 3: 1668-1693. [CrossRef]

6. Einhorn, T. A. 2003. Cox-2: Where are we in 2003? - The role of cyclooxygenase-2 in bone repair. Arthritis Res. Ther. 5: 5-7. [Medline] [CrossRef]

7. Flanagan, A. M. and Chambers, T. J. 1992. Stimulation of bone nodule formation in vitro by prostaglandins E1 and E2. Endocrinology 130: 443-448. [Medline]

8. Gerstenfeld, L. C., Al-Ghawas, M., Alkhiary, Y. M., Cullinane, D. M., Krall, E. A., Fitch, J. L., Webb, E. G., Thiede, M. A. and Einhorn, T. A. 2007. Selective and nonselective cyclooxygenase-2 inhibitors and experimental fracture-healing. Reversibility of effects after short-term treatment. J. Bone Joint Surg. Am. 89: 114-125. [Medline] [CrossRef]

9. Grace, R. F., Edwards, S. R., Mather, L. E., Lin, Y. and Power, I. 2000. Central and peripheral tissue distribution of diclofenac after subcutaneous injection in the rat. Inflammopharmacology 8: 43-54. [CrossRef]

10. Gregory, C. A., Gunn, W. G., Peister, A. and Prockop, D. J. 2004. An Alizarin red-based assay of mineralization by adherent cells in culture: comparison with cetylpyridinium chloride extraction. Anal. Biochem. 329: 77-84. [Medline] [CrossRef]

11. Gregory, L. S. and Forwood, M. R. 2007. Cyclooxygenase-2 inhibition delays the attainment of peak woven bone formation following four-point bending in the rat. Calcif. Tissue Int. 80: 176-183. [Medline] [CrossRef]

12. Hucker, H. B., Zacchei, A. G., Cox, S. V., Brodie, D. A. and Cantwell, N. H. R. 1966. Studies on the absorption, distribution and excretion of indomethacin in various species. J. Pharmacol. Exp. Ther. 153: 237-249.

13. Jung, M., Lees, P., Seewald, W. and King, J. N. 2009. Analytical determination and pharmacokinetics of robenacoxib in the dog. J. Vet. Pharmacol. Ther. 32: 41-48. [Medline] [CrossRef]

14. Kidd, B. L. and Urban, L. A. 2001. Mechanisms of inflammatory pain. Br. J. Anaesth. 87: 3-11. [Medline] [CrossRef]

15. Kirtikara, K., Morham, S. G., Raghow, R., Laulederkind, S. J. F., Kanekura, T., Goorha, S. and Ballou, L. R. 1998. Compensatory prostaglandin E2 biosynthesis in cyclooxygenase 1 or 2 null cells. J. Exp. Med. 187: 517-523. [Medline] [CrossRef] 
16. Kulterer, B., Friedl, G., Jandrositz, A., Sanchez-Cabo, F., Prokesch, A., Paar, C., Scheideler, M., Windhager, R., Preisegger, K.H. and Trajanoski, Z. 2007. Gene expression profiling of human mesenchymal stem cells derived from bone marrow during expansion and osteoblast differentiation. BMC Genomics 8: 70. [Medline] [CrossRef]

17. Lascelles, B. D., Cripps, P. J., Jones, A. and Waterman-Pearson, A. E. 1998. Efficacy and kinetics of carprofen, administered preoperatively or postoperatively, for the prevention of pain in dogs undergoing ovariohysterectomy. Vet. Surg. 27: 568-582. [Medline] [CrossRef]

18. Minamizaki, T., Yoshiko, Y., Kozai, K., Aubin, J. E. and Maeda, N. 2009. EP2 and EP4 receptors differentially mediate MAPK pathways underlying anabolic actions of prostaglandin E2 on bone formation in rat calvaria cell cultures. Bone 44: 1177-1185. [Medline] [CrossRef]

19. Mosmann, T. 1983. Rapid colorimetric assay for cellular growth and survival: Application to proliferation and cytotoxicity assays. J. Immunol. Methods 65: 55-63. [Medline] [CrossRef]

20. Murakami, M., Nakashima, K., Kamei, D., Masuda, S., Ishikawa, Y., Ishii, T., Ohmiya, Y., Watanabe, K. and Kudo, I. 2003. Cellular prostaglandin E2 production by membrane-bound prostaglandin E synthase-2 via both cyclooxygenases-1 and -2 . J. Biol. Chem. 278: 37937-37947. [Medline] [CrossRef]

21. Murakami, M., Naraba, H., Tanioka, T., Semmyo, N., Nakatani, Y., Kojima, F., Ikeda, T., Fueki, M., Ueno, A., Oh-ichi, S. and Kudo, I. 2000. Regulation of prostaglandin E2 biosynthesis by inducible membrane-associated prostaglandin E2 synthase that acts in concert with cyclooxygenase-2. J. Biol. Chem. 275: 32783-32792. [Medline] [CrossRef]

22. Nakamura, A., Dohi, Y., Akahane, M., Ohgushi, H., Nakajima, H., Funaoka, H. and Takakura, Y. 2009. Osteocalcin secretion as an early marker of in vitro osteogenic differentiation of rat mesenchymal stem cells. Tissue Eng. Part C Methods 15: 169-180. [Medline] [CrossRef]

23. Ochi, H., Hara, Y., Asou, Y., Harada, Y., Nezu, Y., Yogo, T., Shinomiya, K. and Tagawa, M. 2011. Effects of long-term administration of carprofen on healing of a tibial osteotomy in dogs. Am. J. Vet. Res. 72: 634-641. [Medline] [CrossRef]

24. Pilbeam, C. C., Raisz, L. G., Voznesensky, O., Alander, C. B., Delman, B. N. and Kawaguchi, H. 1995. Autoregulation of inducible prostaglandin $\mathrm{G} / \mathrm{H}$ synthase in osteoblastic cells by prostaglandins. J. Bone Miner. Res. 10: 406-414. [Medline] [CrossRef]

25. Raisz, L. G. and Woodiel, F. N. 2003. Effects of selective prostaglandin EP2 and EP4 receptor agonists on bone resorption and formation in fetal rat organ cultures. Prostaglandins Other Lipid Mediat. 71: 287-292. [Medline] [CrossRef]

26. Ramirez-Yanez, G. O. and Symons, A. L. 2012. Prostaglandin E2 affects osteoblast biology in a dose-dependent manner: An in vitro study. Arch. Oral Biol. 57: 1274-1281. [Medline] [CrossRef]

27. Redlich, K. and Smolen, J. S. 2012. Inflammatory bone loss: pathogenesis and therapeutic intervention. Nat. Rev. Drug Dis- cov. 11: 234-250. [Medline] [CrossRef]

28. Ricciotti, E. and FitzGerald, G. A. 2011. Prostaglandins and Inflammation. Arterioscler. Thromb. Vasc. Biol. 31: 986-1000. [Medline] [CrossRef]

29. Sakuma, Y., Li, Z., Pilbeam, C. C., Alander, C. B., Chikazu, D., Kawaguchi, H. and Raisz, L. G. 2004. Stimulation of cAMP production and cyclooxygenase- 2 by prostaglandin E2 and selective prostaglandin receptor agonists in murine osteoblastic cells. Bone 34: 827-834. [Medline] [CrossRef]

30. Scutt, A. and Bertram, P. 1995. Bone marrow cells are targets for the anabolic actions of prostaglandin E2 on bone: Induction of a transition from nonadherent to adherent osteoblast precursors. $J$. Bone Miner. Res. 10: 474-487. [Medline] [CrossRef]

31. Shapiro, F. 2008. Bone development and its relation to fracture repair. The role of mesenchymal osteoblasts and surface osteoblasts. Eur. Cell. Mater. 15: 53-76. [Medline]

32. Simon, A. M., Manigrasso, M. B. and O'Connor, J. P. 2002. Cyclo-oxygenase 2 function is essential for bone fracture healing. J. Bone Miner. Res. 17: 963-976. [Medline] [CrossRef]

33. Simon, A. M. and O'Connor, J. P. 2007. Dose and time-dependent effects of cyclooxygenase-2 inhibition on fracture-healing. J. Bone Joint Surg. Am. 89: 500-511. [Medline] [CrossRef]

34. Tanioka, T., Nakatani, Y., Semmyo, N., Murakami, M. and Kudo, I. 2000. Molecular identification of cytosolic prostaglandin E2 synthase that is functionally coupled with cyclooxygenase- 1 in immediate prostaglandin E2 biosynthesis. J. Biol. Chem. 275: 32775-32782. [Medline] [CrossRef]

35. Vane, J. R., Bakhle, Y. S. and Botting, R. M. 1998. Cyclooxygenases 1 and 2. Annu. Rev. Pharmacol. Toxicol. 38: 97-120. [Medline] [CrossRef]

36. Vasileiadis, G. I., Sioutis, I. C., Mavrogenis, A. F., Vlasis, K., Babis, G. C. and Papagelopoulos, P. J. 2011. COX-2 inhibitors for the prevention of heterotopic ossification after THA. Orthopedics 34: 467-472. [Medline] [CrossRef]

37. Xie, C., Liang, B., Xue, M., Lin, A. S. P., Loiselle, A., Schwarz, E. M., Guldberg, R. E., O'Keefe, R. J. and Zhang, X. 2009. Rescue of impaired fracture healing in COX-2-/- mice via activation of prostaglandin E2 receptor subtype 4. Am. J. Pathol. 175: 772-785. [Medline] [CrossRef]

38. Yoon, D. S., Yoo, J. H., Kim, Y. H., Paik, S., Han, C. D. and Lee, J. W. 2010. The effects of COX-2 inhibitor during osteogenic differentiation of bone marrow-derived human mesenchymal stem cells. Stem Cells Dev. 19: 1523-1533. [Medline] [CrossRef]

39. Yuan, Y., Chen, X., Li, S., Wei, X., Yao, H. and Zhong, D. 2009. Pharmacokinetic studies of meloxicam following oral and transdermal administration in Beagle dogs. Acta Pharmacol. Sin. 30: 1060-1064. [Medline] [CrossRef]

40. Zhang, X., Schwarz, E. M., Young, D. A., Puzas, J. E., Rosier, R. N. and O'Keefe, R. J. 2002. Cyclooxygenase-2 regulates mesenchymal cell differentiation into the osteoblast lineage and is critically involved in bone repair. J. Clin. Invest. 109: 1405-1415. [Medline] [CrossRef] 